\title{
TINGKAT ASPIRASI DALAM MEMILIH PROGRAM STUDI DI PERGURUAN TINGGI DITINJAU DARI INTELIGENSI DAN JENIS KELAMIN
}

\author{
AsmadiAlsa \\ Universitas Gadjah Mada
}

INTISARI

Penelitian ini bertujuan untuk mengetahui (1) apakah ada korelasi antara inteligensi dan tingkat aspirasi dalam memilih program studi di perguruan tinggi dan (2) apakah ada per bedaan tingkat aspirasi dalam memilih program studi of perguruan tinggi antara pelajar laki-laki dan pelajar perempuan.

Subjek peneiltiannya sebanyak 210 pelajar lulusan SMA jurusan A3 (IPS), terdiri atas 102 pelajar laki-laki dan 108 pelajar perempuan yang sedang mengikuti bimbingan belajar regulerdi Lembaga Pendidikan Gama Exacta Yogyakarta pada tahun 1996. Variabel tingkat aspirasi diukur dengan skala paired comparison, variabel inteligensi diukur dengan tes inteligensi Advanced Progressive Matrices, sedangkan variabel jenis kelamin dicatal dari identitas subjek yang tertera dalam skala Data yang diperoleh dianalisis dengan metode statistik, menggunakan teknik korelasi product moment dan ujit.

Kesimpulan penelitian ialah (1) terdapat korelasi positif yang sangat signifikan antara inteligensi dan tingkat aspirasi dalam memilih program studi di perguruan tinggi: (2) terdapat perbedaan tingkat aspirasi dalam memilih program studi d perguruan tinggi yang sangat signifikan antara pelajar lakiflaki dan pelajar per empuan. Polajar laki-laki memiliki tingkat aspirasi yang lebih tinggi daripada pelajar perempuan dalam memilh program studi di perguruan tinggi.

Kata kunei : Tingkat aspirasi, program studi, inteligensi, jenis kelamin

Asmadi Alsa, adalah dosen Fakultas Psikologi UGM. Gelar Sarjana Psikologi dan Sarjana Utama (SU) dalam bidang Psikologi diper oleh dari Universitas Gadjah Mada. Memiliki keahlian d bidang Psikologi Pen didikan dan Psikometri.

\section{PENGANTAR}

D erilaku manusia dipengaruhi oleh banyak faktor, bakk internal maupun eksternal. Salah satu faktor intemal adalah aspirasi. Sebagai salah satu aspek psikis, aspirasi dapat menjadi sumber motivasi untuk mencapai suatu tujuan. Aspirasi akan mem- 
buat manusia dinamis dalam menjalani kehidupan; dan lebih dari itu, aspirasi memang diperlukan bagi manusia untuk meraih masa depan. Aspirasi mempunyai objek, misalnya aspirasi kerja, aspirasi pendidikan, dan sebagainya. Pada penelitian ini akan diteliti aspirasi pendidikan, yang secara lebih khusus adalah tingkat aspirași dalam memilih program studi di perguruan tinggi.

Pelajar iulusan SMA sebagai calon mahasiswa dan kelak diharapkan menjadi tenaga-tenaga pembangun bangsa dan negara perlu memiliki aspirasi yang positif dan realistis. Dengan aspirasi yang positif dan realistis, maka kemungkinan mencapai sukses akan lebih besar daripada aspirasi yang negatif dan idealistis. Kesuksesan yang dicapai akan membuat seseorang lebih optimis, meningkatkan rasa percaya dirinya, meningkatkan motivasi, dan hal-hal positif lainnya dalam memandang dan menghadapi kehidupan. Namun demikian dalam kenyataannya seringkali dijumpai para calon mahasiswa tidak realistis dalam menentukan pilihan terhadap program studi di perguruan tinggi yang akan dirnasukinya; atau dengan perkataan tain pilihannya tidak disesuakan dengan kemampuan, bakat dan kesempatan yang ada. Ketidakrealistisan pelajar dalam mernilih program studi dipengaruhi oleh banyak faktor, seperti mengikuti kemauan orangtua, mengikuti pilihan teman, agar mudah mendapatkan pekerjaan, mengejar gengsi, dan sebagainya. Akibatnya, seringkali mereka tidak cocok dengan program studi yang dimasukinya. afau mereka tidak diterima karena tidak memperhitungkan ketatnya tingkat kompetisi yang ada pada pro. gram studi yan dipilihnya.

Aspirasi berasal dari kata aspire, yang artinya "menginginkan" atau "bercita-cita". Hurlock (1979) mengartikan aspirasi sebagai keinginan meraih sesuatu yang lebih finggi daripada keadaannya sekarang. Ahli lain, Sawrey dan Telford (1969) mendefinisikan aspirasi sebagai apa yang ingin dicapai oleh seseorang. Menurut Adi (dalam Gunarsa dan Gunarsa, eds., 1983), aspirasi adalah sama dengan cita-cita, yaitu mengharapkan sesuatu yang lebih tinggi dengan tujuan mendapatkan kemajuan. Dari definisi-definisi di atas dapat disimpulkan bahwa yang dimaksud dengan aspirasi ialah cita-cita atau keinginan yang dikkuti dengan usaha untuk mendapatkan sesuatu yang lebih tinggi atau meningkat dari statusnya sekarang. Keadaan "lebih tinggi" atau "meningkat" tersebut standarnya berbeda antara individu yang satu dengan individu yang lain. Hal ini menunjukkan perbedaan tingkat aspirasi d antara individu.

Menurut Hurlock (1979), aspirasi dapat dikelompokkan menjadi aspirasi positif dan negatii, aspirasi jangka pendek dan jangka panjang, serta aspirasi realistis dan idealistis. Aspirasi positif ialah keinginan meraih kemajuan. Orang yang memiliki aspirasi positif adalah mereka yang ingin mendapatkan yang lebih baik atau lebih tinggi daripada keadaannya sekarang. Umumnya orang mempunyai aspirasi positif, kecuali mereka yang seringkali mengalami kegagalan. Mereka yang sering mengalami kegagalan mungkin mempunyai aspirasi negatif, yaitu keinginan mempertahankan apa yang sudah dicapai selama ini, tanpa keinginan untuk meningkatkan capaiannya. Aspirasi jangka pendek ialah keinginan yang segera dapat dicapai dalam jangka waktu yang relatif singkat, sedangkan aspirasi jangka panjang ialah keinginan yang yang proses pencapaianny a membutuhkan waktu yang relatif lama. Aspirasi realistis ialah keinginan yang didasarkan pada kemampuan dan kesempatan yang ada untuk meraihnya dengan sukses, sedangkan aspirasi idealistis ialah keinginan yang didasarkan pada kemampuan dan kesempatan yang meragukan untuk dapat mencapar kesuksesan. 
Aspirasi yang berkembang mengikuti minat dan didasarkan atas kemampuan merupakan aspirasi yang realistis dan lebih kuat daripada aspirasi yang berkernbang dan dipengaruhi oleh kelompok teman sebaya (Torrance dan Strom, 1967). Pikunas (1978) mengemukakan bahwa aspirasi realistis terutama ditentukan oleh faktorfaktor kognitif, sedangkan aspirasi idealistis terutama ditentukan oleh faktor-faktor afektif. Aspirasi yang realistis, berdasar hasil penelitian Leonard Well (dikutip Sorenson. 1964) terhadap 421 mahasiswa merupakan prediktor yang valid bagi prestasi belajar. Edwards dan Scannefl (1969) juga mengatakan bahwa antara tingkat aspirasi dan prestasi belajarterdapat korelasi positif.

Edwards dan Scannell (1969) mengatakan bahwa tingkat aspirasi adalah harapan seseorang tentang tingkatan hasil yang akan ia capai dalam melakukan tugas. Lebih lanjut mereka mengatakan bahwa tingkat aspirasi didasarkan atas estimasi seseorang mengenai kemampuan dan pengalaman yang dimiliki di dalam memperkirakan seberapa besar tingkat keberhasilan yang dapat diraih dalam menghadapi suatu tugas. Pendapat lain dikemukakan oleh Sorenson (1964) yang mengatakan bahwa tingkat aspirasi melibatkan dua hal, yaitu taraf kesukaran tugas dan jumlah tugas yang akan diterapkan untuk dikerjakan berdasar waktu yang ada. mi berarti bahwa goalyang ditetapkan seseorang untuk dicapai menunįukkan tingka: aspirasi yang dimilikinya.

Edwards dan Scannel (1969) serta McClelland (1987) berpendapat bahwa seseorang akan menerapkan tujuan yang lebih tinggi daripada keadaannya sekarang apabila ia melihat harapan untuk sukses. Tinggi-rendahnya penetapan tujuan oleh individu tersebut disebut sepagai tingkat aspirasi. Hurlock (1979) memandang tingkat aspirasi sebagai suatu tujuan yang dicitacitakan seseorang untuk dicapai dalam waklu tertentu. Lebih lanjut Hurlock (1973). dan juga Kolesnik (1970), mengatakan bahwa apabila seseorang dapa: memastikan bahwa ia akan berhasil meraih tujuan yang telah ditetapkan, maka dapat diindikasikan bahwa ia memiliki aspirasi yang realistis.

Tingkat aspirasi berbeda-beda antara orang yang satu dengan orang yang lain. Kolesnik (1970) dan Suryabrata (1983) mengatakan bahwa suatu prestasi yang bagi seseorang telah menimbulkan pengalaman sukses, bagi orang lain mungkin masih merupakan kegagalan, atau sebaliknya. Mengingat hal tersebut maka pengenalan terha. dap tingkat aspirasi seseorang merupakan hal yang penting, agar dapat dilakukan penyiasatan untuk dapat meraih kesuksesan; karena pengalaman sukses akan menimbulkan terjadinya mobilisasi energi cadangan, yang pada gilirannya akan meningkatkan molivasi seseorang untuk terus mencapai prestasi.

Menurut Hurlock (1979), tingkat aspirasi dipenganui oleh variabel inteligensi, jenis kelamin, minat, nilai-nilai, harapan kelompok, pola asuh orangtua, tingka: kompetisi, pengalaman masa lalu, dan karakteristik kepribadian. Dari variabel-variabel tersebut peneliti tertarik untuk mengetahui keterkaitan antara variabel inteligensi dan jenis kelamin dengan tingkat aspirasi dalam memilih program studi di perguruan tinggi.

Sorenson (1964), Edwards dan Scanne\|l (1969). Koiesnik (1970), dan Suryabrata (1983) berpendapat sama, bahwa pengalaman sukses dan gagal memegang peranan yang besar dalam menentukan tinggirendahnya tingkat aspirasi seseorang. Kesuksesan cenderung meningkatkan aspirasi, sedangkan kegagalan cenderung membuat seseorang untuk mempertahankan tingkat aspirasi atau menurunkan aspirasinya. Selanjutnya Lewin. dkk (dalam Sawrey dan Telford, 1969) dan juga Edwards dan Scannell (1969) berpendapat bahwa se- 
makin banyak pengalaman sukses yang diperoleh seseorang maka semakin tinggi kenaikan aspirasi orang tersebut, sebaliknya, semakin banyak pengalaman gagal yang diperolehnya semakin tajam pula penurunan aspirasinya. Sorenson (1964) mendukung pendapat bahwa kesuksesan dapat meningkatkan aspirasi, akan tetapi ia mengatakan bahwa pengakaman gagal membawa pada tiga kemungkinan reaksi. Kemungkinan pertama ialah menurunkan tingkat aspirasi, kemungkinan kedua menghindari situasi yang telah menyebabkan kegagalan. dan kemungkinan ketiga adalah tetap bertahan dengan tingkat aspirasinya dengan mengabaikan pengalaman gagalnya.

Menurut Sorenson (1964) serta Edwards dan Scannel (1969) bahwa berdasar konfirmasi dari beberapa hasil penelitian, umumnya mahasiswa merencanakan apa yang akan dikerjakannya berdasar pada kemungkinannya untuk berhasil dengan berpedoman pada kapasitas dan abilitas yang dimilikinya. Apabila pendapat tersebut dikaitkan dengan tema penelitian ini, maka pelajar yang memiliki inteligensi tinggi akan memiliki aspirasi yang tinggi dalam memilih program studi; atau dengan perkataan lain ia akan berani memilih program studi yang da ya kompetisinya tinggi dibanding dengan pelajar yang inteligensinya rendah. Strang (dalam Hurlock, 1979) mengatakan bahwa orang cenderung menetapkan tingkat aspirasinya relatif tinggi apabila mereka puas dengan status keberadaannya, atau apabila ia mempunyai keyakinan diri atau efikasi diri yang tinggi.

Individu yang inteligensinya tinggi kemungkinan untuk sukses di bidang akademik relatif lebih besar daripada individu yang inteligensinya rendah. Sebaliknya pengalaman-pengalaman gagal di bidang akademik secara relatit lebih sering dialami oleh individu yang inteligensinya rendah. Akumulasi kegagalan akan membuat individu lebih beraspirasi negatif, sedangkan akumulasi kesuksesan akan menaikkan tingkat aspirasi seseorang. Selain itu menu rut Edwards dan Scannell (1969) pelajar yang memiliki pengalaman sukses akan menetapkan tingkat aspirasinya secara realistis, sedangkan pelajar yang memiliki pengalaman gagal penetapan tingkat aspirasinya adalah tidak realistis dan dipengaruhi oleh banyak variabel.

Kegagalan, menurut Hurlock (1973), di sebabkan oleh (1) keterbatasan kemampuan mental dan fisik, (2) kurangnya pengenalan terhadap potensi yang dimiliki, (3) kurangnya pendidikan dan latihan yang dipertu$\operatorname{kan}_{\mathrm{f}}$ (4) motivasi yang rendah, dan (5) tingkat aspirasi yang tidak realistis.

Berdasar uraian teoritis di atas dapat diasumsikan bahwa semakin tinggi inteligensi yang dimiliki seseorang maka semakin tinggi tingkat aspirasinya. Penelitian yang dilakukan Purnomo (1978) dengan mengambil subjek remaja di Yogyakarta mendukung pernyataan di atas. Hasil penelitiannya menunjukkan bahwa antara $\mathrm{O}$ dan tingkat aspirasi terdapat korelasi positit yang meyakinkan. Penelitian yang dilakukan oleh Davids dan Sidman (dikutip Edwards dan Scannell ${ }_{r}$ 1969) terhadap pelajar SMA juga mendapatkan hasil bahwa terdapat hubungan positif antara tingkat inteligensi dan tingkat aspirasi dalam mengerjakan tugas belajar.

Telah disebutkan bahwa selain inteligensi, peneliti juga tertarik untuk mengaitkan antara jenıs kelamin dengan tingkat aspirasi; karena dalam banyak hal, antara lakilaki dan perempuan terdapat perbedaan. Perbedaan tersebut bukan hanya terdapat pada aspek biologis, tetapi juga pada aspek psikologis dan sosiologis.

Awai dari adanya perbedaan perilaku antara laki-laki dan perempuan banyak ditentukan oleh perbedaan perlakuan yang diberikan oleh lingkungan sosial. Dikatakan 
olei Kartono (1980) bahwa perbedaan misi yang diemban antara lakj-laki dan perempuan selain karena kodrat, juga disebabkan oleh perlakuan lingkungan sosial yang berbeda antara kedua jenis kelamin tersebut. Sejalan dengan pendapat di atas, Marwel (dalam Budiman, 1985) mengatakan bahwa setiap kebudayaan memberikan perlakuan dan peran yang berbeda pada individu berdasarkan atas perbedaan seksual. Pemberian perlakuan dan peran yang berbeda tersebut menghasilkan sifat-sifat yang berbeda antara laki-laki dan perempuan.

Kartono (1980) mengemukakan bahwa sesuai dengan struktur otak dan misi yang diembannya, maka perempuan lebih menyukai hal-hal yang praktis-konkrit, sedangkan laki=laki lebih menyukai hal-hal yang bersifat teoritis-abstrak. Menu rut Broverman dkk (dalam Dagun, 1990) sifal-sifat kaum laki-laki antara lain adalah agresif, bebas, rasional. objektif, tidak mudah terpengaruh aktit, suka kompetisi, tidak suka ketergantungan, dan ambisius. Sebalknya sifat-sifat wanita antara lain adalah pasif, kurang bebas, emosional, subjektif, mudan terpengaruh, tidak suka kompetisi, kurang percaya diri, dan tidak ambisius.

Berdasar pada perbedaan sifat antara laki-laki dan perempuan tersebut, maka sifatsifat bahwa laki-laki lebih ambisius, lebin agresif, lebih suka berkompetisi, dan memiliki rasa percaya diri yang lebih tinggi danpada perempuan, membawa pada suatu asumsi bahwa tingkat aspirasi laki-laki lebih tinggi daripada tingkat aspirasi perempuan.

Berdasar pada asumsi-asumsi teoretik di atas, maka hipotesis penelitian yang diajukan adalah: (1) Ada korelasi positif antara inteligensi dan tingkat aspirasi dalam memilih program studi di perguruan tinggi dan (2) Ada perbedaan tingkat aspirasi dalam memilih program studi di perguruan tinggi antara pelajar laki-laki dan pelajar perempuan. Pelajar laki-laki memiliki tingkat as- pirasi yang lebih tinggi daripada pelajar perempuan dalam memilih program studi di perguruan tinggi.

\section{METODE}

Subjek dalam penelitian ini ialah para pelajar lulusan SMA yang baru saja selesai mengikuti EBTANAS SMA dan sedang mempersiapkan diri untuk mengikuti ujian masukperguruan tinggi negen (UMPTN) tahun ajaran 1996/1997. Jumlan subjek penelitian sebanyak 210, yang terdiri dari 102 pelajar laki-laki dan 108 pelajar perempuan. Mereka merupakan sebagian dari peserta bimbingan belajar reguler tahun 1996 di Lembaga Pendidikan Gama Exacta Yogyakarta.

Metode pengumpulan data yang dipakai untuk mengukur tingkat aspirasi dalam memilin program studi adalah skak paired com parison yang disusun berdasar 12 program studi ilmu sosial yang ditetapkan. Keduabelas program studi tersebut dipasang-pasangkan antara yang satu dengan lain, sehingga seluruhnya terdapat sebanyak 66 pasangan program studi. Sebelum subjek diminta untuk memilin salah satu dari setiap pasangan program studi, terlebih dulu diben informasi tentang rasio antara jumlah yang diterima dan jumlah pendaftar untuk masingmasing program studi selama empat tahun terakhir. Tinggi-rendahnya sekortingkat aspirasi subjek dalam memilih program studi didasarkan atas hasil kali antara banyaknya frekuensi masing-masing program studi yang dipilih subjek dengan bobot yang dimiliki oleh masing-masing program studi tersebut. Bobot program studi ini berkisar antara 1 sampai dengan 12 , yang penetapannya didasarkan atas urutan tinggi-rendahnya rasio antara jumlah ca lon yang diterima dan jumlah pendaftar untuk masing-masing program studi. Rasio yang paling tinggi diberi bobot 12 sedangkan rasio yang paling rendah diberi bobot 1 . Semakin tinggi sekor 
yang diperoleh subjek maka semakin tinggi tingkat aspirasinya dalam memilih program studi, sebaliknya semakin rendah sekor yang diperoleh subjek, maka semakin rendah tingkat aspirasinya dalam memilih program studi.

Program studi di perguruan tinggi yang dimaksudkan dalam penelitian iniadalah 12 program studi dari keseluruhan 21 program studi ilmu-ilmu sosial yang ada di Universitas Gadjah Mada. Keduabeias program studi tersebut ialah Ekonomi dan Pembangunan, Filsafat, Psikologi, Antropologi, Sejarah, Hubungan internasional, ilmu Komunikasi, Sosiologi, Akuntansi, Sastra Indonesia, Sastra Inggris, dan Sastra Jawa. Pengambilan keduabelas program studi tersebut mewakili tiga kategori berdasar banyaknya jumlah pendattar selama empat tahun terakhir; masing-masing empat program studi mewakili kategori yang pendaftarnya banyak empat program studi mewakili kategori yang pendaftaranya sedang, dan empat program studi mewakili kategori yang pendaftarnya sedikit. Dari keduabelas program studi tersebut kemudian dipasang-pasangkan satu sama lain, sehingga seluruhnya diperoleh 66 pasang program studi. Keenampuluhenam pasang program studi inilah yang dimintakan kepada subjek, agar mereka memilih salah satu program studi dari setiap pasangan secara forced-choice.

Metode yang dipakai untuk mengukur inteligensi ialah dengan menggunakan tes inteligensi Advanced Progressive Matrices, sedangkan data jenis kelamin dicatat dari identitas subjek yang tertera dalam skala.

Metode analisis data yang digunakan ialah metode statistik dengan menggunakan teknik korelasi product moment dan uji-t. Teknik korelasi product momentdimaksudkan untuk mengetahui ada-tidaknya hubungan antara inteligensi dan tingkat aspirasi dalam memilih program studi, sedangkan uji-t dimaksudkan untuk mengetahui ada- tidaknya perbedaan aspirasi dalam memilih program studi antara pelajar laki-laki dan pelajar perempuan.

\section{HASLL}

Dari analisis data yang dilakukan diperoleh hasil sebagai berikut:

(1) Koefisien korelasi antara inteligensi dan tingkat aspirasi dalam memilih program studi di perguruan tinggi (rxy) sebesar 0,282 dengan $p<0,01$. Ini berarti terdapat korelasi positif yang sangat signifikan antara inteligensi dan tingkat aspirasi dalam memilih program studi d perguruan tinggi.

(2) Rasio perbedaan tingkat aspirasi dałam memilin program studi antara pelajar laki-laki dan pelajar perempuan (nilai $t$ ) sebesar 3,209 dengan $p<0,01$. mi berarti ada perbedaan tingkat aspirasi dalam memilih program studi di perguruan tinggi yang sangat signifikan antara pelajar laki-laki dan pelajar perempuan. Pelajar laki-laki memiliki tingkat aspirasi yang lebih tinggi $(X=396,092)$ daripada pelajar perempuan $(X=357,860)$ dalam memilih program studi di perguruan tinggi.

\section{PEMBAHASAN}

Penelitian ini mendapatkan hasil bahwa ada hubungan positif yang sangat signitikan antara inteligensi dan tingkat aspirasi dalam memilih studi. Semakin tinggi inteligensi subjek cenderung semakin tinggi pula tingkat aspirasinya dalam program studi di perguruan tinggi. Sebaliknya, semakin rendah tingkat inteligensi subjek maka semakin rendah pula tingkat aspirasinya dalam memilih program studi di perguruan tinggi. Dengan perkataan lain bahwa subjek yang inteligensinya tinggi cenderung lebih bera- 
ni memilih program studi yang tingkat kompetisinya tinggi dibanding dengan subjek yang tingkat inteligensinya rendah. Implikasi daripada adanya hubungan positif antara inteligensi dan tingkat aspirasi dalam memilih program studi ini, mengindikasikan bahwa pelajar Iulusan SMA memiliki aspirasi yang realistis dalam memilih program studi di perguruan tinggi. Mereka sudah mendasarkan diri pada kemampuan yang dimiliki dan besar-kecilnya peluang atau kesempatan yang ada dalam memilith program studi. Sikap realistis tersebut sejalan dengan teori perkembangan, bahwa pelajar lulusan SMA yang masuk dalam periode perkembangan remaja akhir, memiliki aspirasi yang realistis dalam hubungannya dengan penentuan karır untuk masa depannya (Grinder 1978). Hurlock (1973) juga mengatakan bahwa pada remaja awal, mungkin pelajar masih memiliki aspirasi yang tidak realistis. Akan tetapi melalui pengalaman-pengalaman yang diperoleh dalam proses perkembangannya, pada masa remaja akhır mereka sudah memiliki aspirasi yang lebih reaifstis.

Terujinya hupotesis penelitian yang pertama ini sekaligus menunjukkan bahwa asumsi teoritis yang menyebutkan bahwa antara inteligens dan tingkat aspirasi terdapat hubungan yang positit, berlaku pula terhadap tingkat aspirasi dalam memilih program studi di perguruan tinggi.

Hipotesıs penelitian kedua yang menyatakan bahwa tingkat aspirasi pelajar laki-laki lebih tinggi daripada tingkat aspirasi pelajar perempuan dalam memilih program studi df perguruan tinggi, juga teruji kebenarannya. Suatu fakta yang tidak bisa dipungkiri bahwa program studi yang tingkat kompetisinya tinggi adalah program studi yang lulusannya laku di pasar kerja. Masalah kerja berkaitan langsung dengan masalah sosial-ekonomi, khususnya penghasilan yang diperoleh sebagai imbalan dari kegiatan bekerja. Perila- ku individu tidak lepas dari pengaruh lingkungan serta nilai-nilai sosial dan budaya di mana ia hidup. Nilai-nilaj dan norma sosial di Indonesia lebih menuntut kaum laki-laki untuk bertanggungjawab dalam memenuhi kebutuhan ekonomi keluarga. Kedudukan atau peran anak laki-laki dan anak perempuan sejak dari lingkungan keluarga telah dikonstruksi berdasar nilai-nilai sosial budaya, yang menempatkan anak perempuan pada tugas mengurus rumah, memasak, mengasuh anak, dan peran domestik lainnya. Selain itu batasan-batasan bersikap dan berperilaku lebih banyak dikenakan pada anak perempuan. Menurut Toffler(1974). penempatan peran semacam ini seringkali mengekang keleluasaan anak perempuan untuk mengambil peran. Mereka bahkan bisa merasa canggung dan kurang percaya din dalam menghadapi kehidupan-kehidupan mendatang.

Perlakuan-perlakuan sosial seperti diuraikan ditas mungkin membawa dampak bagi pelajar perempuan dalam memilih program studi di perguruan tinggi, karena secara sosial mereka merasa tidak dituntut untuk memilith program studi yang lulusannya laku keras di pasar kerja. Hal ini dapat menyebabkan tingkat aspirasinya dalam memilih program studi di perguruan tinggi lebih rendah daripada yang dimiliki pelajar laki-laki.

Tentang lebiti rendahnya tingkal aspirasi pelajar perempuan abanding dengan tingkat aspirasi pelajar laki-laki dalam memılih program studi tersebut, dapat pula dijelaskan berdasardua pendapat berikut ini. Menurut Hurlock (1973), aktivitas bekerja bagi perempuan bukanlah merupakan jilihan selamanya untuk pengembangan karı. Sekalipun perempuan memutuskan untuk bekerja setelah selesai studi, tapi mereka lebih memilih bidang-bidang pekerjaan yang dapat dikombinasikan dengan peran mereka sebagai ibu rumah tangga kelak. Senada dengan 
pendapat Hurlock, Grinder (1978) mengatakan bahwa banyak wanita yang bekerja bukan berdasar atas car eerorientedmelainkan berdasar atas work oriented, yang melihat kerja sebagai kegiatan yang menarik untuk. dilakukarı, tapi secara intrinsik kurang penting dibandirı denganı perannya sebagai ibu rumah tangga (homemakers). Oleh sebab itu, bagi wanita, bekerja bukan merupakan sentral dari gaya hidupnya. Namun demikian Grinder (1978) juga mengatakan bahwa dengan adarıya gerakan feminisme, jumlah wanita yang career oriented, yaitu yang memandarıg kerja sebagai sentrai dari perencanaan kehidupan masa depan mereka, semakin bertambah.

\section{PENUTUP}

Penelitian ini menyimpulkan bahwa terdapat korelasi positif yang sangat signifikan antara inteligensi darı tingkat aspirasi dalam memilih program di perguruan tinggi. Semakin tinggi inteligensi semakin tinggi tingkat aspirasi subjek dalam memilih program studi semakin rendah tirıgkat irteligensi subjek semakin rendah tingkat aspirasinya dalam memilih program studi perguruan tinggi.

Penelitiarı juga menghasilkan kesimpulan bahwa terdapat perbedaan tingkat aspirasi dalam memilih program studi d perguruan tinggi yang sarıgat signifikan antara pelajar laki-laki dan pelajar perempuan. Tingkat aspirasi pelajar laki-laki lebih tinggi daripada tingkat aspirasi pelajar perempuan dalam memilih program studi di perguruan tinggi. $\Xi$

\section{DAFTAA PUSTAKA}

Budiman, A. 1985. Pembagian Kerja SecaraSeksual. Jakarta: PT. Gramedia.
Dagun, SM. 1990. Psikologi Koluarga Jakarta: Rineka Cipta.

Edwards, A.J. and Scannell, DP. 1969. Educational Psychology. Pennsytvania: International Texbook Company.

Grinder, R.E. 1978. Adolescence, Second Edition. New York Johrı Wiley \& Sons.

Gunarsa, S.D. darı Gunarsa, Y.S.D. (Eds.) 1983. Psikologi Perkembangan anak dan remaja. Jakarta: Perıerit PT. BPK. Gurıurıg Mulia.

Hurlock, E. 1973. Adolescent Development. New Delhi: Tata Mc-Graw-Hill Publishing Company, Inc.

- 1979. Personality Development. New Delhi: Tata McGraw-Hill Publishing Company, Inc.

Kartono, K. 1980. Teori Kepribadian. Bandung: Penerit Alumni.

Kolesnik, W.B. 1970. Educational Psychology, Second Edition. New York: Mc Graw-Hill Book Company.

McCleltand, D.C. 1987. HumanMotivation. New York: Cambridge University Press, Cambridge.

Pikunas, J. 1978. Human Development. Tokyo: McGraw Hill Koga Kusha, Ltd:

Purnomo, H.B. 1978. Huburigan Antara $\mathbf{Q}$ dengan Tingkat Aspirasi Aemaja. Skripsi. Yogyakarta: Fakultas Psikologi Universitas Gadjah Mada.

Sawrey, J.M. and Telford, C.W. 1969. Educational Psychology. Boston: Alyn and Bacon Inc.

Sorenson, H. 1954. Psychology in Educa- 
tion. New Delhi: Tala McGraw-Hill Pub- Toffler,A. 1974. Leaming for Tomorow. New lishing $\mathrm{Co}_{\text {., }}$ Ltd. York: Random House Inc.

Suryabrata, S. 1983. Proses Belajar Meng- Torrance, E.P. and Strom, R.D. 1967. Menajar of Perguruan of Perguruan Tinggi. Yogyakarta: Penerbit Andi Offset. tal Heatth and Achievement. New York: John Wiley and Sons inc. 